\title{
Value of Triplicated Inferior Pedicle Breast Reduction in Improving Cosmetic Outcome in Upper Outer Quadrant Breast Cancer Patients
}

\author{
SAMY A. ABD EL RAHMAN, M.D.*; AHMED G. OSMAN, M.D.*; AHMED M. GAD, M.D.**; \\ MOHAMED R.M. ABO SHADY, M.Sc.* and KAMAL M.K. ELSAID, M.D.* \\ The Departments of General Surgery* and Plastic Surgery**, Faculty of Medicine, Ain Shams University
}

\begin{abstract}
Background: Breast is the true mirror of femininity. Breast cancer is one of the diseases that affect the psychological state of women, not only because of the complications it entails, but also because of the negative impact of treatment on women psychologically and physically.
\end{abstract}

Aim of Study: The aim of this work is to assess the effect of triplicated inferior pedicle technique on improving cosmetic outcome in patients with breast cancer in upper outer quadrant.

Patients and Methods: This study conducted at Ain Shams University hospitals, starting January 2020 till May 2020 with follow up 6 months. The study include 15 patients from 3050 year. This prospective study started with 15 Female patients with breast cancer in upper outer quadrant or upper pole lesion. During the period of the study at Ain-Shams University Hospitals. The data was collected and presented as followed in several tables and figures.

Results: In our study the mean value of immediate postoperative SN-N was $21 \mathrm{~cm}$. After 6 months the mean value of postoperative $\mathrm{SN}-\mathrm{N}$ was $21.5 \mathrm{~cm}$. In the current study the mean value of preoperative inframammary fold- nipple distance (IMF-N) was $17.27 \mathrm{~cm}$. In our study mean value of immediate postoperative IMF-N was $7.33 \mathrm{~cm}$, and After 6 months the mean value of postoperative IMF-N was $8 \mathrm{~cm}$. So, triplicated inferior pedicle is to obtain the benefits and avoid the most annoying complication and maintain the shape of breast after breast reduction without significant difference in postoperative complications.

Conclusion: Breast reduction is a procedure, which has evolved tremendously over the years due to the continuous and ongoing quest to achieve the objective of reducing the breast size, improving breast shape and relocating the nipple areola complex, while minimizing scars and also preserving lactation and innervation to the nipple-areola complex.

Key Words: Triplicated inferior pedicle breast-Cosmetic outcome - Upper outer quadrant breast cancer patients.

Correspondence to: Dr. Mohamed R.M. Abo Shady, E-Mail: doc mido10@yahoo.com

\section{Introduction}

BREAST is the true mirror of femininity. Breast cancer is one of the diseases that affect the psychological state of women, not only because of the complications it entails, but also because of the negative impact of treatment on women psychologically and physically [1]

Breast cancer, according to Egyptian National Cancer Institute, is the most common site of cancer in women in Egypt as it accounts for about 38.8\% of total malignancies among Egyptian females; it is an important cause of mortality among women [2]

Oncoplastic breast conserving surgery is a modern surgical approach. It allows a surgical treatment that covers oncology and reconstruction aspects avoiding cosmetic sequelae. It is a varied surgery composing of many differentmodalities and techniques [3].

Breast reconstruction is becoming increasingly important due to changes in patient expectations and demand. There is growing recognition that immediate reconstruction in appropriately selected women can combine an oncological and aesthetic procedure in one operation with excellent results. Increasingly, breast surgery is being performed by breast surgeons trained in oncoplastic techniques who can offer immediate reconstruction with both therapeutic and economic option [4]

Tumors in the upper outer quadrant (UOQ) are the most frequent site of tumor location. They are associated with better survival compared with other quadrants [3].

The inferior pedicle technique is highly versatile with applicability to almost all breast sizes and sternal notch to nipple distances [5] 
The indications for an inferior pedicle oncoplastic reduction are women with breast cancer who wish to preserve their breasts and have moderate-sized to large breasts with ptosis. A reduced breast will tolerate radiation therapy better than a large breast, and aesthetic results have been shown to be superior [1].

A common criticism of the technique is its tendency to inferior descent (pseudo ptosis or bottoming out) due to great stretch ability and extendibility of skin and by the weight of the inferior pedicle. This can leave a significantly empty upper pole [6].

Triplicated inferior pediclebreast reduction is one of the recent techniques, described by Katsaros et al., [6].

The inferior pedicle is divided vertically to half way into three separate parenchymal columns with a common base. The medial and lateral parenchymal columns are then sutured together superiorly creating a cone of tissue around the middle pedicle to form upper pole to the breast and minimize bottoming [6].

Aim of the work:

The aim of this work is to assess the effect of triplicated inferior pedicle technique on improving cosmetic outcome in patients with breast cancer in upper outer quadrant.

\section{Patients and Methods}

This study conducted at Ain Shams University hospitals, starting January 2020 till May 2020 with follow-up 6 months. The study include 15 patients from 30-50 year.

\section{Patient selection:}

Triplicated Inferior Pedicle Breast Reduction technique was used for women with mild, moderate, marked breast hypertrophy and also with breast skin redundancy.

\section{All patients were subjected to:}

Inclusion criteria:

- Female patients with breast cancer in upper outer quadrant.

- Any upper pole lesion for excision.

- All age groups are included (30y-50y).

- Node negative patients.

- T1-T2 node positive patients.
- T3 patients with large breast volume (upper outer quadrant).

Exclusion criteria:

- Distant metastasis.

- Tumors away from upper outer quadrant.

- History of previously treated ipsilateral breast cancer.

- Inflammatory tumors, T4 breast cancer.

- Diffuse micro-calcification.

- Patients with history of breast reconstruction surgeries.

- Patients with history of psychological instability.

Every patient was evaluated via the following:

Full history taking: Name, age, address, contact number, special habits (e.g., smoking), marital status, number of pregnancies and offspring and use of hormonal treatment.

Complaint and patient concern: Shape, size, breast pain, back pain, neck pain, skin rash under breast, difficulty to find clothes, bra strap marks, comments from others (embarrassment), difficulty to stand upright, difficulty to find sleeping, past history of breast diseases, family history of similar condition and past history on any medical conditions.

General examination: Weight in $\mathrm{kg}$, height in meter, body mass index (BMI).

\section{Local examination:}

Exposure from above umbilicus.

Inspection: From two different planes and under surface of the breast.

- Skin: Normal, stretched, pigmented.

- Nipple: Direction, retraction, displacement, discoloration.

- Areola: Eczema.

Others as dimpling, peau de orange, umbilicus, upper limp, lymph edema, discharge.

Palpation:Warmth, tenderness.

- Surface: Smooth, granular, nodular.

- Draining L.N: Axillary (ant, post, lat, apical, medial group).

\section{Investigation:}

- Laboratory investigations (CBC, renal function tests, liver function tests, and prothrombin time and concentration). 
- Radiological examination as breast ultra sound and/or mammography.

- Breast Ultrasound and/or mammography were done for all patients to exclude any associated breast problems which may interfere with the procedure.

- Magnetic Resonance Imaging.

- Fine Needle Aspiration Cytology or True Cut Needle Biopsy.

- Metastatic workup before operations.

- Informed consent will be taken including all the details of the procedure and the post-operative information and the possible complications, preoperative photography in antero-posterior, oblique and lateral views for documentation.

Assessment: Our technique assessed according to:

Intra-operative criteria:Time of the operation and amount of blood loss and difficulty.

Post-operative complication: Infection, loss of sensation, delayed healing, loss of nipple areola complex, seroma, hematomas, color changes, dimples, Bottoming out, Irregularities, asymmetry and satisfaction about the scar.

\section{Method:}

Operative strategy overview:

Triplicated Inferior Pedicle Breast Reduction has been described that is designed to allow an effective reduction in breast volume to be performed while, at the same time, providing an excellent shape.

\section{Results}

Preoperative marking:

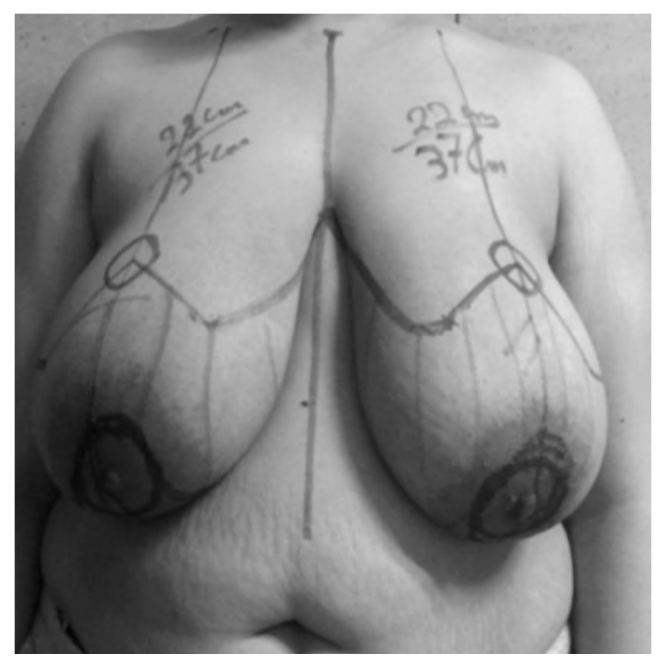

Fig. (1): Picture of preoperative marking.

\section{Technique:}

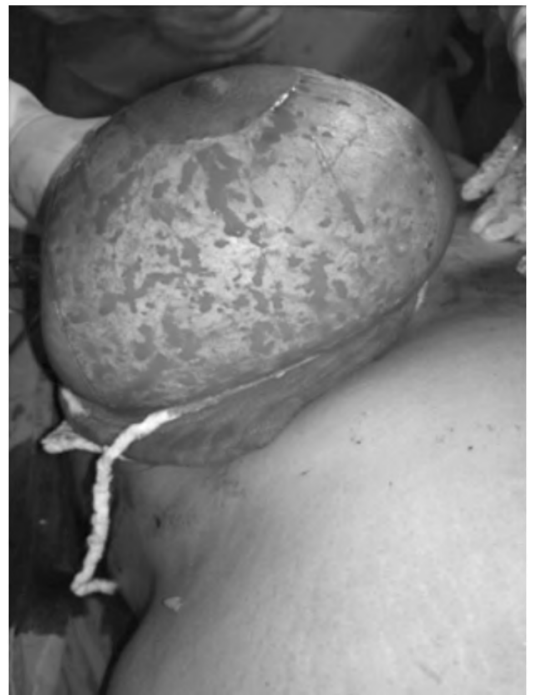

Fig. (2): Skin de-epithelialization of inferior pedicle.

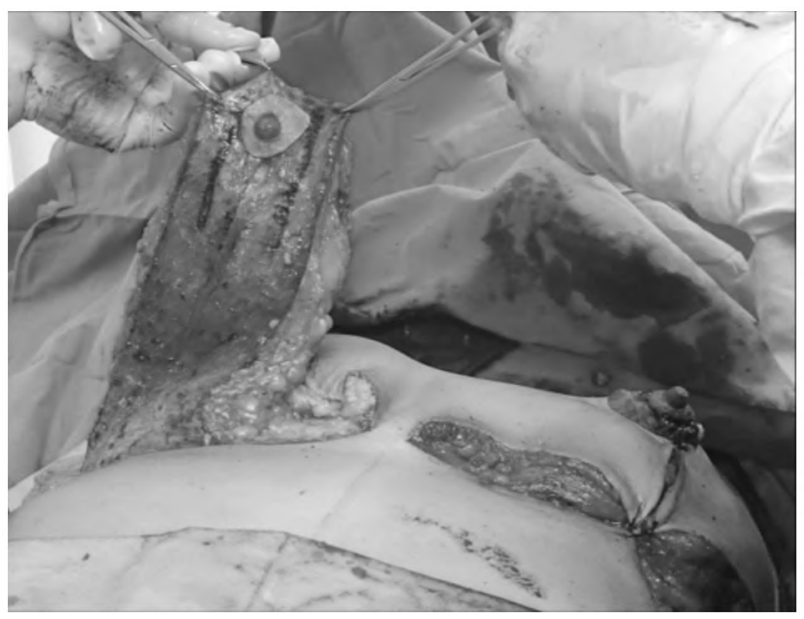

Fig. (3): The inferior pedicle separation.

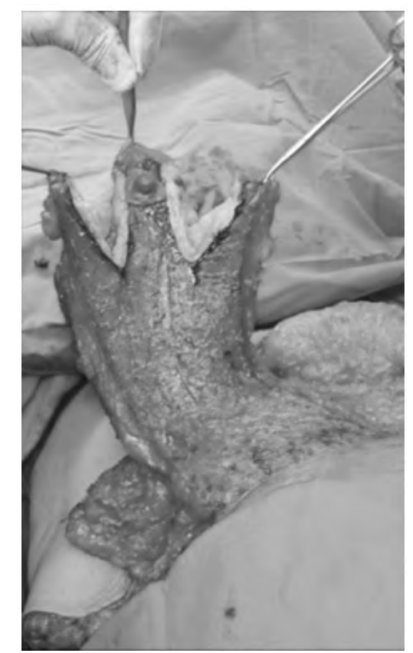

Fig. (4): The inferior pedicle is divided into three columns. 


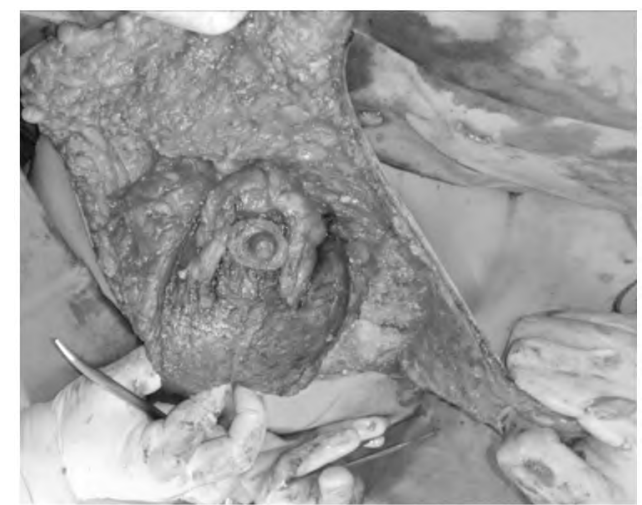

Fig. (5): Suturing the two lateral columns together and suspension of the flap to clavipectoral fascia.

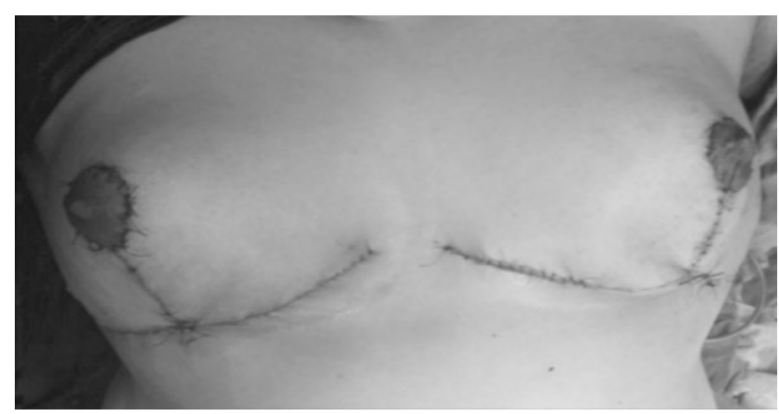

Fig. (6): Skin is closed with prolene.

\section{Follow-up:}

All patients were subjected to immediate postoperative observation of breast shape and symmetry. Post-operative monitoring to nipple viability and hematoma in the first day. The drains are removed in the first post-operative day. All patients are given instructions to limit physical activity for 2 weeks. One week post-operative confirm state of nipples, flaps, and breast symmetry. Soft elastic non wire support bra is advised in the first 2 weeks. Follow-up for 6 months to assess final breast shape. Measure breast projection, upper pole fullness, sterna notch to nipple distance, inframammary fold to nipple distance immediate postoperative and after six months to detect bottoming out if happened. We detect bottoming out if inframammary fold to nipple distance increase from immediate post-operative to 6 months postoperative more than $2 \mathrm{~cm}$.

\section{Statistical analysis:}

Data will be coded, entered and analyzed using SPSS (statistical package for social sciences) version 20. Descriptive statistics will be done for study as regards all collected variables. The quantitative variables will be compared using paired $t$ test or one-way ANOVA. The comparison of qualitative variables will be performed using chi-square test or Fisher's exact test. $p$-value level of signifi- cance: $p>0.05$ : non-significant, $p<0.05$ : Significant, $p<0.01$ : Highly significant.

Table (1): Demographic characteristics in study population.

\begin{tabular}{ccc} 
& \multicolumn{2}{c}{ Demographic characteristics } \\
\cline { 2 - 3 } & $\mathrm{N}(15)$ & $\%$ \\
\hline Age: & \multicolumn{2}{c}{$39.87 \pm 5.79$} \\
Mean $\pm \mathrm{SD}$ & \multicolumn{2}{c}{32} \\
Minimum & \multicolumn{2}{c}{50} \\
Maximum & \multicolumn{2}{c}{} \\
Marital status: & 1 & 6.67 \\
Single & 2 & 80 \\
Married & & 13.33 \\
Divorced & 15 & 100 \\
Special habit: & 0 & 0 \\
No & & \\
Yes & 15 & 100 \\
Smoking: & 0 & 0 \\
No & & \\
Yes & 2 & 13.33 \\
Past history: & 2 & 13.33 \\
DM & &
\end{tabular}

Table (2): Pre \& postoperative sternal notch to nipple distances in study population.

\begin{tabular}{llcccc}
\hline & \multicolumn{2}{l}{ Sternal notch to nipple distances } & & \\
\cline { 2 - 4 } & $\begin{array}{c}\text { Pre- } \\
\text { operative }\end{array}$ & $\begin{array}{c}\text { Imme- } \\
\text { diate }\end{array}$ & $\begin{array}{c}\text { After } \\
6 \text { months }\end{array}$ & $\begin{array}{c}\text { Statistically } \\
\text { value } \\
\text { significant }\end{array}$ \\
\hline Mean \pm SD & $35.8 \pm 3.45$ & $21.53 \pm 0.64$ & $22.2 \pm 0.68$ & $<0.0001$ & Sig. \\
Minimum & 30 & 20 & 21 & & \\
Maximum & 42 & 22 & 23 & & \\
\hline
\end{tabular}

Statistical test used: Two sample $t$-test.

- $p$-value $\leq 0.05$ considered statistically significant ( $95 \%$ confidence interval).

Six months postoperative, sternal notch to nipple distance range from $21 \mathrm{~cm}$ to $23 \mathrm{~cm}$ with mean value 22.2 and standard deviation 0.68 . The data are highly significant as shown in Table (2).

Table (3): Show relation between preoperative $\&$ immediate as a confirmatory test.

\begin{tabular}{lcccc}
\hline & $\begin{array}{c}\text { Sternal notch to nipple distances } \\
\text { Preoperative }\end{array}$ & $\begin{array}{c}\text { Immediate } \\
\text { value }\end{array}$ & $\begin{array}{c}\text { Statistically } \\
\text { significant }\end{array}$ \\
\hline Mean \pm SD & $35.8 \pm 3.45$ & $21.53 \pm 0.64$ & $<0.0001$ & Sig. \\
\hline
\end{tabular}

Statistical test used: Two sample $t$-test.

- $p$-value $\leq 0.05$ considered statistically significant ( $95 \%$ confidence interval).

Comparison of variables which give positive results with ANOVA test by the Dunnett's multiple comparisons test to identify the variable that made the significant change. 
Table (4): Show relation between preoperative \& postoperative as a confirmatory test.

\begin{tabular}{lcccc}
\hline & \multicolumn{2}{c}{ Sternal notch to nipple distances } & $\begin{array}{c}p \text { - } \\
\text { value }\end{array}$ & $\begin{array}{c}\text { Statistically } \\
\text { significant }\end{array}$ \\
\cline { 2 - 3 } Mean \pm SD & $35.8 \pm 3.45$ & $22.2 \pm 0.68$ & $<0.0001$ & Sig. \\
\hline
\end{tabular}

Statistical test used: Two sample $t$-test.

Table (5): Show relation between immediate \& postoperative as a confirmatory test.

\begin{tabular}{lcccc}
\hline & \multicolumn{2}{c}{ Sternal notch to nipple distances } & $\begin{array}{c}p \text { - } \\
\text { value }\end{array}$ & $\begin{array}{c}\text { Statistically } \\
\text { significant }\end{array}$ \\
\cline { 2 - 3 } & Preoperative & After 6 months & & \\
\hline Mean \pm SD & $21.53 \pm 0.64$ & $22.2 \pm 0.68$ & $<0.0001$ & N.S \\
\hline
\end{tabular}

Statistical test used: Two sample $t$-test.

Table (6): Pre \& postoperative inframammary fold to nipple distance in study population.

\begin{tabular}{|c|c|c|c|c|c|}
\hline & \multicolumn{3}{|c|}{$\begin{array}{l}\text { Inframammary fold to } \\
\text { nipple distances }\end{array}$} & \multirow{2}{*}{$\begin{array}{c}p- \\
\text { value }\end{array}$} & \multirow{2}{*}{$\begin{array}{r}\text { Statistically } \\
\text { significant }\end{array}$} \\
\hline & $\begin{array}{c}\text { Pre- } \\
\text { operative }\end{array}$ & $\begin{array}{l}\text { Imme- } \\
\text { diate }\end{array}$ & $\begin{array}{l}\text { After } \\
6 \text { months }\end{array}$ & & \\
\hline Mean \pm SD & $17.27 \pm 2.28$ & $7.33 \pm 0.49$ & $8 \pm 1.09$ & $<0.0001$ & Sig. \\
\hline Minimum & 15 & 7 & 7 & & \\
\hline Maximum & 22 & 8 & 10.5 & & \\
\hline
\end{tabular}

Statistical test used: Two sample $t$-test.

Six months postoperative IMF-N range from $7 \mathrm{~cm}$ to $10.5 \mathrm{~cm}$ with mean value 8 and standard deviation 1.09 . The data are highly significant as shown in Table (6).

Table (7): Show relation between preoperative \& immediate as a confirmatory test.

\begin{tabular}{ccccc}
\hline & \multicolumn{2}{c}{$\begin{array}{c}\text { Inframammary fold to } \\
\text { nipple distances }\end{array}$} & $\begin{array}{c}p^{-} \\
\text {value }\end{array}$ & $\begin{array}{c}\text { Statistically } \\
\text { significant }\end{array}$ \\
\cline { 2 - 3 } & Preoperative & Immediate & & \\
\hline Mean \pm SD & $17.27 \pm 2.28$ & $7.33 \pm 0.49$ & $<0.0001$ & Sig. \\
\hline
\end{tabular}

Statistical test used: Two sample $t$-test.

Comparison of variables which give positive results with ANOVA test by the Dunnett's multiple comparisons test to identify the variable that made the significant change.

Table (8): Show relation between preoperative $\&$ postoperative as a confirmatory test.

\begin{tabular}{ccccc}
\hline & \multicolumn{2}{c}{$\begin{array}{c}\text { Inframammary fold to } \\
\text { nipple distances }\end{array}$} & $\begin{array}{c}p- \\
\text { value }\end{array}$ & $\begin{array}{c}\text { Statistically } \\
\text { significant }\end{array}$ \\
\cline { 2 - 5 } & Preoperative After 6 months & & Sig. \\
\hline Mean \pm SD & $17.27 \pm 2.28$ & $8 \pm 1.09$ & $<0.0001$ & . \\
\hline
\end{tabular}

Statistical test used: Two sample $t$-test.
Table (9): Show relation between immediate \& postoperative as a confirmatory test.

\begin{tabular}{ccccc}
\hline & \multicolumn{2}{c}{$\begin{array}{c}\text { Inframammary fold to } \\
\text { nipple distances }\end{array}$} & $\begin{array}{c}p \text { - } \\
\text { value }\end{array}$ & $\begin{array}{c}\text { Statistically } \\
\text { significant }\end{array}$ \\
\cline { 2 - 3 } & $\begin{array}{l}\text { Immediate } \\
\text { Mean } \pm \text { SD }\end{array}$ & After 6 months & & \\
\hline T.33 \pm 0.49 & $8 \pm 1.09$ & 0.4433 & N.S \\
\hline
\end{tabular}

Statistical test used: Two sample $t$-test.

Table (10): Esthetic outcome after 6 months in study population.

\begin{tabular}{|c|c|c|c|c|c|c|}
\hline & \multicolumn{4}{|c|}{ Doctor satisfaction } & \multirow{3}{*}{$\begin{array}{c}p- \\
\text { value }\end{array}$} & \multirow{3}{*}{$\begin{array}{l}\text { Statistically } \\
\text { significant }\end{array}$} \\
\hline & \multicolumn{4}{|c|}{ Immediate After 6 months } & & \\
\hline & $\mathrm{N}(15)$ & $\%$ & $\mathrm{~N}(15)$ & $\%$ & & \\
\hline Satisfied & 13 & 86.67 & 14 & 93.33 & $>0.9999$ & N.S \\
\hline Un satisfied & 2 & 13.33 & 1 & 6.67 & & \\
\hline
\end{tabular}

Statistical test used: Two sample $t$-test.

The esthetic outcome after 6 months revealed that one patient was bad, two patients were good and seven patients were excellent.

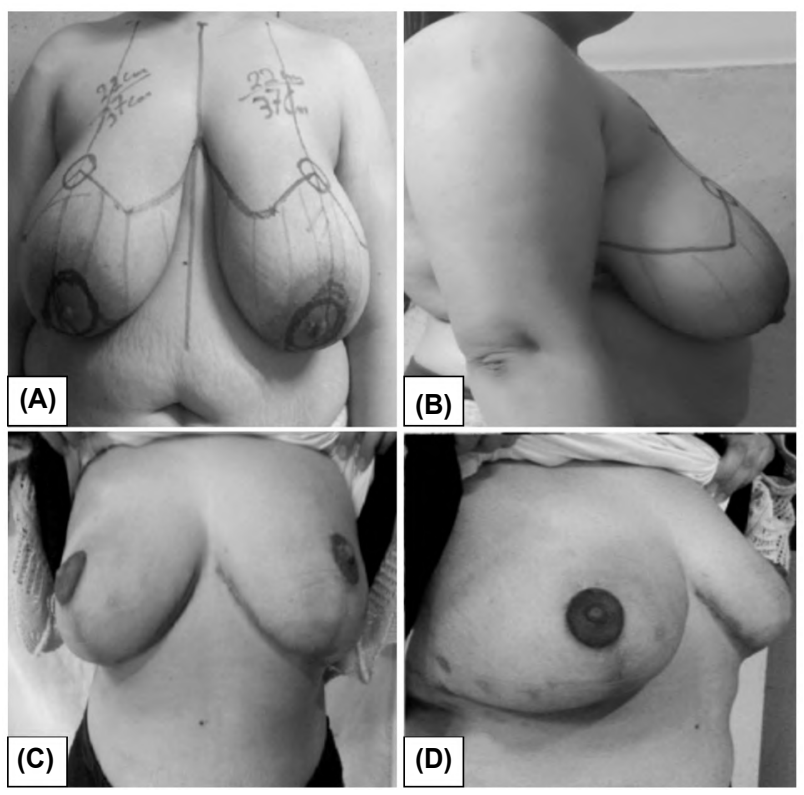

Fig. (7): Picture of case (No. 1) of triplicated inferior pedicle technique. A: Preoperative postero-anterior view. B: Preoperative lateral view. C: 6 Months postoperative postero-anterior view. D: 6 Months postoperative lateral view.

\section{Discussion}

Breast is the true mirror of femininity. Breast cancer is one of the diseases that affect the psychological state of women, not only because of the complications it entails, but also because of the negative impact of treatment on women psychologically and physically [1]. Breast cancer, accord- 
ing to Egyptian National Cancer Institute, is the most common site of cancer in women in Egypt as it accounts for about $38.8 \%$ of total malignancies among Egyptian females; it is an important cause of mortality among women [2] .

Oncoplastic breast conserving surgery is a modern surgical approach. It allows a surgical treatment that covers oncology and reconstruction aspects avoiding cosmetic sequelae. It is a varied surgery composing of many different modalities and techniques [4].

Breast reconstruction is becoming increasingly important due to changes in patient expectations and demand. There is growing recognition that immediate reconstruction in appropriately selected women can combine an oncological and aesthetic procedure in one operation with excellent results. Increasingly, breast surgery is being performed by breast surgeons trained in oncoplastic techniques who can offer immediate reconstruction with both therapeutic and economic option [3]

The inferior pedicle technique is highly versatile with applicability to almost all breast sizes and sternal notch to nipple distances [5].

A common criticism of the technique is its tendency to inferior descent (pseudo ptosis or bottoming out) due to great stretch ability and extendibility of skin and by the weight of the inferior pedicle. This can leave a significantly empty upper pole [6].

Triplicated inferior pedicle breast reduction is one of the recent techniques, described by Katsaros et al., [6].

The inferior pedicle is divided vertically to half way into three separate parenchymal columns with a common base. The medial and lateral parenchymal columns are then sutured together superiorly creating a cone of tissue around the middle pedicle to form upper pole to the breast and minimize bottoming [6].

Our theses carried out on 15 female patients suffering from breast cancer and breast hypertrophy, patients were operated with triplicated inferior pedicle. In our study the mean age was 39.8 years. This is more or less in agreement with Bitik and Uzun [7] who had found the mean age of their patients was 44 years.

Also, Simsek et al., Góes et al., and Temel et al., [8-10] all those mentioned that mean age of their patients were $(42.7,42$ and 32 years) respectively.
In our study the mean duration of surgery was 4.3 hours. This finding is against Roje et al., [11] who had shorter mean duration of surgery that was 2 hours. This difference may be due to having different techniques in his study.

In our study the mean weight of reduction per breast was $1320 \mathrm{gm}$. It is more or less in agreement with Temel et al., [10] who had the mean weight of reduction $1250 \mathrm{gm}$ per breast.

Also, Roje et al., in 2012, Temel et al., in 2015 and Simsek et al., in 2016 [8,10,11] are mention that mean weight of reduction per breast $1057 \mathrm{gm}$, $1250 \mathrm{gm}$ and $1472 \mathrm{gm}$ respectively. These results are against with Zic et al., [5] who had the mean weight of reduction per breast was $975 \mathrm{gm}$.

In our current study, the mean value of preoperative sternal notch-to-nipple distance ( $\mathrm{SN}-\mathrm{N})$ was $35.8 \mathrm{~cm}$. This is more or less in agreement with Zic et al., [5] who had the mean value of preoperative sternal notch-to-nipple distance $36.3 \mathrm{~cm}$.

Other study done by Simsek et al., [8] who had the mean value of preoperative sternal notch-tonipple distance $35 \mathrm{~cm}$ and Temel et al., [10] who had the mean value of preoperative sternal notchto-nipple distance $35 \mathrm{~cm}$.

Also, other study against our results done by Brown et al., [12] who had in his study the mean value of preoperative sternal notch-to-nipple distance $32.2 \mathrm{~cm}$, Roje et al., [11] who had smaller mean value of preoperative sternal notch-to-nipple distance that was $28 \mathrm{~cm}$ and Bitik and Uzun [7] who had also smaller mean value of preoperative sternal notch-to-nipple distance that was $27.4 \mathrm{~cm}$.

In our study the mean value of immediate postoperative SN-N was $21 \mathrm{~cm}$. After 6 months the mean value of postoperative $\mathrm{SN}-\mathrm{N}$ was $21.5 \mathrm{~cm}$.

This agree with study done by Bitik and Uzun [7] had the mean value of immediate postoperative MCL-N $19.6 \mathrm{~cm}$ and after long term follow-up was $19.8 \mathrm{~cm}$. Also, Temel et al. [10] reported in his study that the mean value of first month postoperative $\mathrm{SN}-\mathrm{N} 20 \mathrm{~cm}$ and after one year follow-up was $20 \mathrm{~cm}$.

In the current study the mean value of preoperative inframammary fold-nipple distance (IMF-N) was $17.27 \mathrm{~cm}$.

This results are supported with study done by Brown et al., [12] who had the mean value of preoperative (IMF-N) $16.4 \mathrm{~cm}$ and Simsek et al., 
[8] who had the mean value of preoperative (IMFN) $16.7 \mathrm{~cm}$.

In our study mean value of immediate postoperative IMF-N was $7.33 \mathrm{~cm}$, and After 6 months the mean value of postoperative IMF-N was $8 \mathrm{~cm}$.

In study done by Bitik and Uzun [7] that agree with our results the mean value of immediate postoperative IMF-N $6.7 \mathrm{~cm}$ and after long term follow-up was $7 \mathrm{~cm}$.

Also, Temel et al., [10] had retraction and upward displacement of inframammary fold due to pulling effect of dermal flap. Temel et al., [10] had the mean value of first month INF-N $10.5 \mathrm{~cm}$ and the mean value after the first year of INF-N $11 \mathrm{~cm}$.

In the current study, Postoperative complication for revealed that no patients had seroma, hematoma, Dog ear and $\mathrm{T}$-junction breakdown, these results are in agreement with Temel et al., [10] had no seroma, hematoma, Dog ear and had delayed wound healing in $(3.75 \%)$.

Also, Zic et al., [5] reported that had $\mathrm{T}$-junction breakdown in (7.6\%) and Yazici et al., [13] who had no cases of hematoma.

Infection was $(6.6 \%)$. this is more or less in agreement with Brown et al., [12] who had infection in $(3.7 \%)$ and Roje et al., [11] who had infection in $(6.8 \%)$. Also agree with study done by Temel et al., [10] who had no incidence of infection and Zic et al., [5] who had higher incidence of infection that was $(11.5 \%)$.

Hypertrophic scar was $(6.6 \%)$ and this result are supported by results done by Roje et al., [11] had hypertrophic scar in (5.1\%), Zic et al., [5] had keloid scarring in (2.6\%), Temel et al., [10] had hypertrophic scar in $(2.5 \%)$.

Slight decreased nipple sensation in (33\%). This is more or less in agreement with Yazici et al., [13] who had decreased nipple sensation in $(12.5 \%)$.

Partial N/A necrosis in small area in one patient occurred in (6.6). It is more or less in agreement with Zic et al., [5] who had no total N/A necrosis $(0 \%)$ but partial necrosis occurred in $(7.6 \%)$, Roje et al., [11] who had N/A necrosis in (3.4\%) and Simsek et al., [8] had N/A necrosis in (2\%). Katsaros et al., [6] had no N/A necrosis ( $0 \%)$, Brown et al., [12] had no N/A necrosis $(0 \%)$ and Temel et al., [10] had no N/A necrosis.
Flap necrosis occurred in (6.6\%). And this agrees with study done by Brown et al., [12] who had partial skin flap necrosis in $(3.7 \%)$ and Simsek et al., [8] who had partial skin flap necrosis in (4\%).

Slight asymmetry in $(13.3 \%)$ but they didn't annoy the patients and acceptable, It is more or less in agreement with Zic et al., [5] who had asymmetry in $(30.8 \%)$.

No patient had DVT $(0 \%)$ or pulmonary embolism $(0 \%)$, no patient required reoperation $(0 \%)$. Roje et al., [11] had pulmonary embolism in (1.6\%). Acute myocardial infarction in $(1.6 \%)$ and DVT in $(1.6 \%)$. Yazici et al., [13] had $(25 \%)$ of patients need scar revision, (3\%) of patients need additional breast reduction. Katsaros et al., [6] need reoperation in $(2 \%)$ for persistent exaggerated upper pole.

In the current study patient satisfaction 6 months postoperative was $(93.3 \%)$ one of them because of scar but she was satisfied with her breast shape. And this agrees with Roje et al., [11] had overall patient satisfaction $(96 \%)$. Patient satisfaction with Yazici et al., [13] (81.25\%).

So, triplicated inferior pedicle is to obtain the benefits and avoid the most annoying complication and maintain the shape of breast after breast reduction without significant difference in postoperative complications.

\section{Conclusion:}

Breast reduction is a procedure, which has evolved tremendously over the years due to the continuous and ongoing quest to achieve the objective of reducing the breast size, improving breast shape and relocating the nipple areola complex, while minimizing scars and also preserving lactation and innervation to the nipple-areola complex.

The inferior pedicle technique still is the most widely used operation for breast reduction. The very low rates of nipple necrosis and the greater preservation of nipple sensibility give it certain advantages over other techniques. Postoperative pseudo ptosis or "bottoming out", is very common complication after inferior pedicle.

The phenomena of "bottoming out" and "stargazing" continues to challenge surgeons using the inferior pedicle breast reduction technique, especially in large-volume reductions.

In our hands, the use of triplicated inferior pedicle has proven a safe and effective option for dealing with this difficult problem. The triplicated inferior pedicle breast reduction technique proved 
to be better than inferior pedicle without modification in attaining and maintaining a perfect conical and protruding breast, upper pole fullness and less bottoming out. It is easy, reliable, needs no special skills, has a fast learning curve. It improves Cosmetic Outcome in Upper Outer Quadrant Breast Cancer Patients.

\section{References}

1- URBAN C., RIETJENS M., EL-TAMER M., SACCHINI V.S.: editors. Oncoplastic and reconstructive breast surgery. Milan: Springer, 2013.

2- LEE M., BASSIOUNI R., SPARROW N., IKETANI A., BOOHAKER R., MOSKOWITZ C., et al.: The CT20 peptide causes detachment and death of metastatic breast cancer cells by promoting mitochondrial aggregation and cytoskeletal disruption. Cell death \& disease, 5 (5): e1249e, 2014.

3- SPEAR S.L., SERUYA M., CLEMENS M.W., TEITELBAUM S. and NAHABEDIAN M.Y.: Acellular dermal matrix for the treatment and prevention of implantassociated breast deformities. Plastic and Reconstructive Surgery, 127 (3): 1047-58, 2011.

4- SCHRENK P.: Retroareolar Breast Cancer Treated with Central Quadrantectomy. Oncoplastic Breast Surgery: Springer, p. 149-52, 2015.

5- ZIC R., VLAJCIC Z., DEWING D., ZAMBELLI M. and STANEC Z.: The "dermal cage": A modification of the inferior pedicle breast reduction. Aesthetic Plastic Surgery, 37 (2): 364-71, 2013.

6- KATSAROS J., HARVEY I. and CAPLASH Y.: The triplicated inferior pedicle-a new method for breast re- duction and mastopexy. Journal of Plastic, Reconstructive \& Aesthetic Surgery, 63 (7): 1131-5, 2010.

7- BITIK O. and UZUN H.: Analysis of Lower Breast Pole Length and Nipple-Areola Complex Position Following Superior Pedicle, Short Horizontal Scar Breast Reduction. Aesthetic Plastic Surgery, 40 (5): 690-8, 2016.

8- SIMSEK T., ENGIN M.S., ABDULLAYEV A., KUCUKER I., DEMIR A. and EROGLU L.: Accordion-style pedicle suspension in inferocentral pedicled mammoplasty. Journal of Plastic Surgery and Hand Surgery, 50 (5): $307-$ 14, 2016.

9- GOES J.C.S., LANDECKER A., LYRA E.C., HENRÍQUEZ L.J., GÓES R.S. and GODOY P.M.: The application of mesh support in periareolar breast surgery: clinical and mammographic evaluation. Aesthetic Plastic Surgery, 28 (5): 268-74, 2004.

10- TEMEL M., KARAKAS A.O., DOKUYUCU R. and TÜRKMEN A.: "The Dermal Internal Brassiere Flap", A New Modification of Inferior Pedicle Breast Reduction Technic. Aesthetic Plastic Surgery, 39 (3): 350-8, 2015.

11- ROJE Z., ROJE Z., MILOSEVIC M., VARVODI'C J., MANCE M.: Current Trends in Breast Reduction. Collegium Antropologicum, 36: 657-68, 2012.

12- BROWN R.H., IZADDOOST S., BULLOCKS J.M.: Preventing the "bottoming out" and "star-gazing" phenomena in inferior pedicle breast reduction with an acellular dermal matrix internal brassiere. Aesthetic Plastic Surgery, 34 (6): 760-7, 2010.

13- YAZICI I., DEMIR U., FARIZ S., VURAL A.C., KARAKAYA E.I., CAVUSOGLU T., et al.: Meridian pediclebased breast shaping in reduction mammaplasty: A technical modification. Aesthetic Plastic Surgery, 37 (2): 372 9, 2013. 


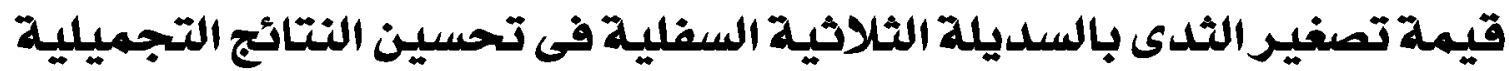

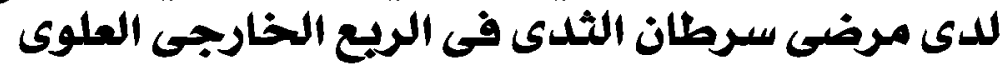

جراحة ترميم الثدى هى طريقة جراجية حديثة. يتيع العلاج الجراحى الذى يغطى علم الأودام وجوانب إعادة البناء وتجنب الآثار التجميلية.

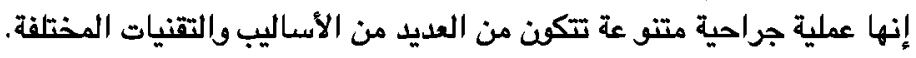

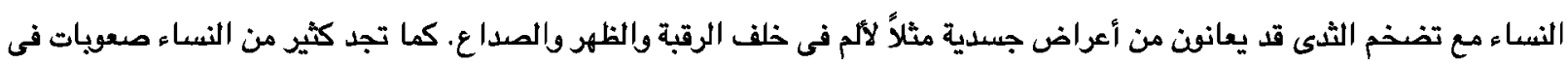
الثود على الملابس التى تتاسبها دون أن تبلو بدينة وصعوبات فى ممارسة الرياضة بسعبب حركة الثدى.

تصغير الثى هو عملية جميلية شائعة، وأنه لا يهدف فقط فى تصغير حجم الثدى ليتناسب مع حجم الفرد ولكن أيضاً للتغلب على علم الراحة التى تسبيها كبر الثدى، وسيوء الشكل وتهدله.

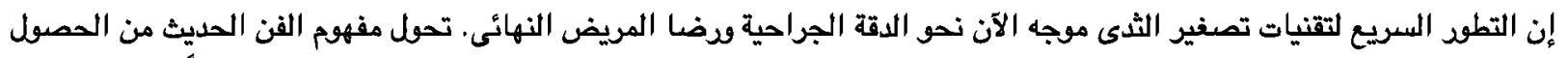

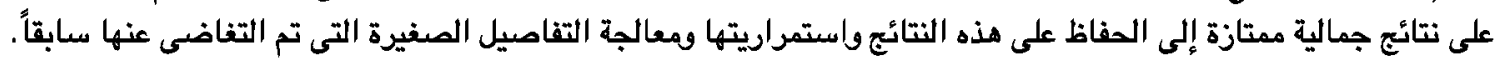

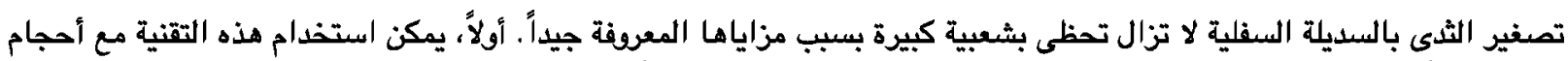

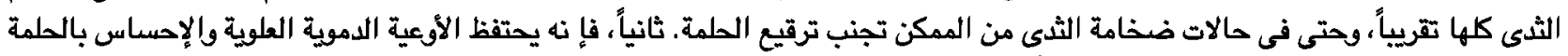

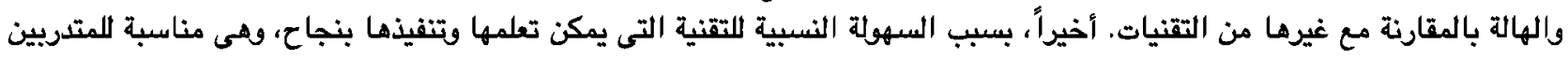

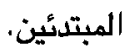

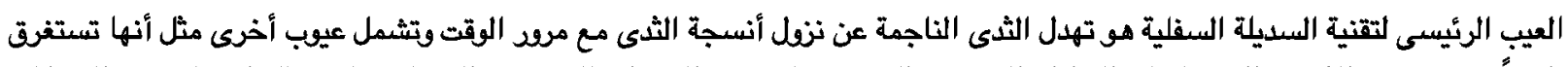

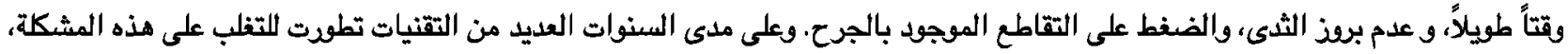

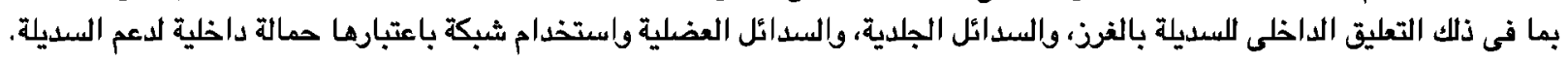

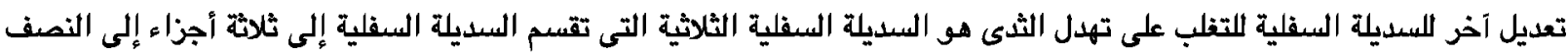

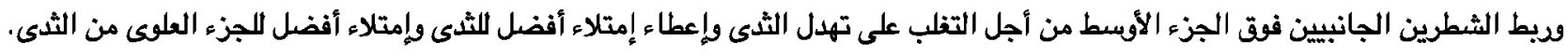
الذلك فإن السديلة الثلاثية السفلية تعطى نتائج جمالية أفضل دون زيادة فى المضاعفات. 